bahasa \& sastra, Vol. 14, No.1, April 2014

\title{
PEMBELAJARAN BAHASA INDONESIA BERBASIS STRATEGI BELAJAR BAHASA SEBAGAI PENDUKUNG IMPLEMENTASI KURIKULUM 2013
}

\author{
Iis Lisnawati \\ Universitas Siliwangi Tasikmalaya, Kopertis Wilayah IVJawa Barat \\ Korespondensi: Jln. Siliwangi No. 24 Tasikmalaya \\ Pos-el: is.lisnawati@yahoo.co.id
}

\begin{abstract}
Abstrak
Pendekatan sainstifik (observing, questioning, associating, experimenting, dan networking) yang digunakan dalam Kurikulum 2013 menuntut pembelajar bukan hanya sampai menguasai konsep dan mencoba atau membuat, tetapi harus sampai mengomunikasikan hasil analisis, temuan, atau produknya kepada pembelajar atau pihak lain. Karena itu, pembelajaran bahasa Indonesia bukan hanya diarahkan pada penguasaan kompetensi gramatikal, melainkan juga harus diarahkan pada penguasaan kompetensi sosiolinguistik, kompetensi wacana, dan kompetensi strategi. Untuk menguasai kompetensikompetensi tadi diperlukan strategi yang tepat dalam pembelajaran bahasa. Salah satu strategi yang dapat digunakan adalah Strategi Belajar Bahasa. Strategi Belajar Bahasa adalah tindakan spesifik yang diambil oleh pelajar untuk membuat belajar lebih mudah, lebih cepat, lebih menyenangkan, lebih mandiri, lebih efektif, dan lebih dapat dialihkan kepada situasi baru. Strategi Belajar Bahasa meliputi strategi memori, strategi kognitif, strategi kompensasi, strategi metakognitif, strategi afektif, dan strategi sosial.
\end{abstract}

Kata-Kata Kunci: Pembelajaran bahasa Indonesia, strategi belajar bahasa

\begin{abstract}
The scientific approach (observing, questioning, associating, experimenting and networking) employed in the 2013 curriculum requires students to not only master, experiment and create concepts but also to communicate results of analysis, findings or products to other students/parties. Indonesian teaching, therefore, is oriented not only for mastery of grammatical competence but also sociolinguistic, discourse ad strategic competences. To acquire such competences, an appropriate teaching strategy is called for. One such strategy is the so-called the language learning strategy, which refers to specific actions carried out by students to make learning easier, faster, more enjoyable, more independent, more effective and more directed towards new situations. This strategy includes memory, cognitive, compensation, metacognitive, affective and social strategies.
\end{abstract}

Key Words: Indonesian teaching, language learning strategy 


\section{PENDAHULUAN}

Dimensi kompetensi lulusan yang dikembangkan oleh Kurikulum 2013 adalah sikap, pengetahuan, dan keterampilan (Permendikbud No. 54 Tahun 2013). Orientasi kompetensi ini tentu saja menuntut para guru di lapangan untuk menciptakan proses pembelajaran yang mengarah pada kompetensi tersebut, sebagaimana dikemukakan dalam Permendikbud No. 65 Tahun 2013) yang menyatakan bahwa proses pembelajaran pada satuan pendidikan diselenggarakan secara interaktif, inspiratif, menyenangkan, menantang, memotivasi peserta didik untuk berpartisipasi aktif, serta memberikan ruang yang cukup bagi prakarsa, kreativitas, dan kemandirian sesuai dengan bakat, minat, dan perkembangan fisik serta psikologis peserta didik. Untuk itu setiap satuan pendidikan melakukan perencanaan pembelajaran, pelaksanaan proses pembelajaran serta penilaian proses pembelajaran untuk meningkatkan efisiensi dan efektivitas ketercapaian kompetensi lulusan.

Selanjutnya dijelaskan pula bahwa sikap diperoleh melalui aktivitas“ menerima, menjalankan, menghargai, menghayati, dan mengamalkan". Pengetahuan diperoleh melalui aktivitas" mengingat, memahami, menerapkan, menganalisis, mengevaluasi, mencipta. Keterampilan diperoleh melalui aktivitas" mengamati, menanya, mencoba, menalar, menyaji, dan mencipta".

Untuk memenuhi harapan tadi, Kurikulum 2013 menjadikan pendekatan sainstifik sebagai pendekatan yang digunakan dalam proses pembelajaran. Pendekatan sainstifik meliputi observing, questioning, associating, experimenting, dan net working. Pendekatan ini menuntut pembelajar bukan hanya sampai menguasai konsep dan mencoba atau membuat, tetapi harus sampai mengomunikasikan hasil analisis, temuan, atau produknya kepada pembelajar atau pihak lain. Karena itu, pembelajaran bahasa Indonesia sebagai penghela ilmu pengetahuan bukan hanya diarahkan pada penguasaan kompetensi gramatikal, melainkan juga harus diarahkan pada penguasaan kompetensi sosiolinguistik, kompetensi wacana, dan kompetensi strategi sehingga komunikasi yang dilakukan pembelajar efektif. Penguasaan kompetensi strategi dapat dilakukan melalui pengintegrasian Strategi Belajar Bahasa dalam pembelajaran bahasa Indonesia.

\section{HAKIKAT PROSES PEMBELAJARAN MENURUT KURIKULUM 2013}

Kurikulum adalah seperangkat rencana dan pengaturan mengenai tujuan, isi, dan bahan pelajaran serta cara yang digunakan sebagai pedoman penyelenggaraan kegiatan pembelajaran untuk mencapai tujuan pendidikan tertentu. Berdasarkan pengertian tersebut, ada dua dimensi kurikulum, yang pertama adalah rencana dan pengaturan mengenai tujuan, isi, dan bahan pelajaran, sedangkan yang kedua adalah cara yang digunakan untuk kegiatan pembelajaran.

Pendekatan belajar yang dipilih berbasis pada teori tentang taksonomi tujuan pendidikan yang dalam lima dasawarsa terakhir secara umum sudah dikenal luas. Berdasarkan teori taksonomi tersebut capaian pembelajaran dapat dikelompokkan dalam tiga ranah yakni: ranah kognitif, afektif dan psikomotor.

Proses pembelajaran sepenuhnya diarahkan pada pengembangan ketiga ranah tersebut secara utuh/holistik. Artinya, pengembangan ranah yang satu tidak bisa dipisahkan dengan ranah lainnya. Dengan demikian, proses pembelajaran secara utuh melahirkan kualitas pribadi yang mencerminkan 
keutuhan penguasaan sikap, pengetahuan, dan keterampilan.

\section{HAKIKAT STRATEGI BELAJAR BAHASA}

Secara etimologi strategi berasal dari kata Yunani kuno strategia yang berarti keahlian dalam seni perang. Secara lebih khusus strategi melibatkan pengelolaan pasukan, kapal, atau pesawat udara yang optimal yang direncanakan (Oxford, 1990: 7).

Pengelolaan secara maksimal dilakukan dengan tujuan memenangkan perang sebagaimana dikemukakan Oxford (2003: 8) bahwa strategia berarti langkah-langkah atau tindakan yang diambil untuk tujuan memenangkan perang. Ketika strategi digunakan sebagai istilah pembelajaran bahasa strategi diartikan sebagai taktik atau pola yang dilakukan oleh seorang pengajar dalam proses belajar bahasa sehingga peserta didik dapat lebih leluasa berpikir dan dapat mengembangkan kemampuan kognitifnya secara lebih mendalam dengan menggunakan bahasa yang baik dan benar (Iskandarwassid dan Sunendar, 2008: 3).

Uraian di atas secara tersurat menyatakan bahwa strategi pembelajaran meliputi kegiatan yang dilakukan oleh pengajar dan kegiatan yang dilakukan oleh pembelajar. Kegiatan yang dilakukan oleh pembelajar disebut strategi belajar. Sebagaimana dikemukakan oleh Wenden dan Joan Robin (1987: 7-8) bahwa strategi belajar diartikan sebagai berbagai kegiatan yang digunakan pembelajar untuk memahami yang mereka pelajari.

Sejalan dengan pendapat di atas O'Malley dan Chamot (1990:1) mengemukakan bahwa strategi belajar adalah pikiran atau prilaku khusus yang digunakan individu untuk membantu mereka memahami, belajar, atau mempertahankan informasi baru. Memahami materi pembelajaran pada hakikatnya merupakan tujuan pembelajaran. Dalam hubungan ini O'Malley dan Chamot (1990) mengemukakan bahwa "strategi belajar adalah pikiran dan tindakan sadar yang dilakukan pembelajar untuk mencapai tujuan pembelajaran". Muho dan Aida Kurani (2011: 177) berpendapat sama dengan mengemukakan bahwa strategi belajar bahasa adalah tindakan yang spesifik, perilaku, taktik, atau teknik yang memfasilitasi pencapaian bahasa target oleh pembelajar.

Dengan strategi belajar bahasa pembelajar bukan hanya mencapai tujuan, melainkan juga dapat meningkatkan kemampuan berbahasa. Oleh karena itu, menurut Bialystok ( $\mathrm{Su}$, 2005: 46) strategi belajar bahasa adalah pemilihan sarana untuk memanfaatkan informasi yang tersedia untuk meningkatkan kompetensi dalam bahasa kedua.

Sejalan dengan pendapat di atas Cohen, dkk. (1996: 3) menyatakan bahwa strategi belajar bahasa digunakan dengan tujuan eksplisit untuk membantu peserta didik meningkatkan pengetahuan dan pemahaman mereka tentang bahasa sasaran. Strategi belajar bahasa adalah pikiran yang sadar dan perilaku yang digunakan oleh siswa untuk memfasilitasi tugas-tugas pembelajaran bahasa dan untuk personalisasi proses pembelajaran bahasa.

Karena dapat meningkatkan kompetensi bahasa, strategi belajar bahasa memberikan kontribusi bagi kemampuan berbahasa pembelajar. Dalam hubungan ini Rubin ( $\mathrm{Su}, 2005$ : 46) mengemukakan bahwa strategi belajar bahasa adalah strategi yang memberikan kontribusi pada pengembangan sistem bahasa yang dibangun pembelajar.

Sistem bahasa yang dikuasai pembelajar pada hakikatnya diperoleh melalui pemprosesan informasi. Dalam kaitan ini O'Malley dan Chamot (1990: 34), dan Su (2005: 46) mengemukakan 
bahwa strategi bahasa belajar adalah cara khusus pengolahan informasi yang meningkatkan pemahaman, pembelajaran, atau pemertahanan informasi.

Pemrosesan informasi oleh pembelajar melalui tahap-tahap tertentu, yaitu tahap pemerolehan, tahap penyimpanan, dan tahap pemanggilan informasi ketika diperlukan. Dalam hubungan ini Oxford (1990: 8) berpendapat bahwa strategi belajar bahasa adalah kegiatan yang digunakan oleh pembelajar untuk membantu pemerolehan, penyimpanan, pencarian, dan penggunaan informasi.

Sejalan dengan pendapat di atas Ehrman dan Oxford (2008: 312) menyatakan bahwa strategi adalah langkah-langkah yang disadari atau perilaku yang digunakan oleh pembelajar untuk meningkatkan pemerolehan, penyimpanan, pemertahanan, pemanggilan, dan penggunaan informasi baru.

Secara lebih spesifik Oxford (1990: 8) mengemukakan bahwa strategi belajar bahasa adalah tindakan spesifik yang diambil oleh pembelajar untuk membuat belajar lebih mudah, lebih cepat, lebih menyenangkan, lebih mandiri, lebih efektif, dan lebih dapat dialihkan kepada situasi baru.

Pemrosesan informasi merupakan proses mental pembelajar. Oleh karena itu, proses belajar bahasa adalah langkah-langkah dan prilaku mental yang digunakan pembelajar dalam mempelajari bahasa baru dan juga digunakan untuk mengarahkan diri dan berupaya terlibat dalam proses belajarnya. Oleh karena itu, strategi belajar bahasa pada hakikatnya adalah kegiatan yang dilakukan atas inisiatif pembelajar sendiri. Hal ini sejalan dengan pendapat Azrien, dkk. (2011: 48) yang menyatakan bahwa dalam konteks dunia sekarang, pendidikan tidak hanya berfokus pada perolehan pengetahuan dan mencapai nilai yang baik dalam ujian, tetapi juga pada peningkatan potensi pembelajar untuk mengarahkan pembelajaran dan kemampuan untuk mengatasi tantangan lingkungan belajar mereka sendiri. Pembelajar bertanggung jawab untuk pembelajaran mereka sendiri. Mereka tidak lagi dilihat sebagai individu yang pasif sebagai penerima informasi, mereka juga aktif terlibat dalam kegiatan pembelajaran yang memfasilitasi terbentuknya hubungan antara informasi yang ada dan pengetahuan baru. Dalam hubungan ini Querol (2010: 24) mengemukakan bahwa strategi belajar bahasa dalam sains diklasifikasikan sebagai inisiasi. Inisiasi dalam pembelajaran bisa berupa inisiasi siswa atau inisiasi guru.

Berdasarkan pendapat-pendapat di atas dapat disimpulkan bahwa strategi belajar bahasa adalah cara khusus yang dilakukan pembelajar untuk meningkatkan pemerolehan, penyimpanan, pemertahanan, pemanggilan, dan penggunaan informasi sehingga mempermudah dan mempercepat penguasaan bahasa, baik reseptif maupun produktif, baik lisan maupun tulis.

Menurut Oxford (1990: 9-14) strategi belajar bahasa memiliki karakteristik berikut

a) Berkontribusi untuk mencapai tujuan utama kompetensi komunikatif

Penggunaan strategi belajar bahasa yang tepat berorientasi pada pencapaian kompetensi komunikatif. Pengembangan kompetensi komunikatif memerlukan interaksi yang realistis antara pembelajar dengan penggunaan bahasa yang bermakna secara kontekstual. Strategi belajar bahasa membantu pembelajar berpartisipasi aktif dalam komunikasi otentik. Strategi tersebut beroperasi baik dalam cara umum maupun cara khusus untuk mendorong pengembangan kompetensi komunikatif. Misalnya strategi metakognitif membantu 
pembelajar untuk mengatur kognisi mereka sendiri untuk fokus, merencanakan, mengevaluasi kemajuan mereka menuju kompetensi komunikatif. Strategi Afektif mengembangkan kepercayaan diri dan ketekunan yang diperlukan pembelajar untuk melibatkan diri secara aktif dalam belajar bahasa. Hal ini merupakan persyaratan untuk mencapai kompetensi komunikatif. Strategi sosial meningkatkan interaksi dan pemahaman yang lebih empatik yang merupakan dua hal yang diperlukan untuk mencapai kompetensi komunikatif.

Kompetensi pembelajar dapat tumbuh melalui strategi dengan bertindak dengan cara tertentu untuk mendorong aspek-aspek tertentu dari kompetensi komunikatif yang harus dicapai, yaitu kompetensi gramatikal, kompetensi sosiolinguistik, kompetensi wacana, dan kompetensi strategi. Misalnya, penggunaan strategi memori, seperti meninjau struktur dan penggunaan strategi kognitif, seperti penalaran deduktif dan analisis kontrastif memperkuat ketepatan penggunaan gramatika. Penggunaan strategi sosial, seperti mengajukan pertanyaan, bekerja sama dengan pembelajar lainnya membantu mengembangkan kompetensi sosiolinguistik.

b) Memungkinkan peserta didik untuk menjadi lebih mandiri

Strategi belajar bahasa mendorong kemandirian pembelajar lebih besar. Kemandirian sangat penting bagi pembelajar karena mereka tidak akan selalu bersama-sama dengan pengajar yang membimbing mereka ketika mereka menggunakan bahasa di luar kelas. Selain itu, kemandirian sangat penting untuk pengembangan kemampuan berbahasa secara aktif .

Banyak pembelajar bahasa (bahkan orang dewasa) yang pasif dan terbiasa disuapi. Karena itu, harus ada upaya untuk melatih pembelajar untuk lebih mengandalkan diri mereka sendiri dan menggunakan strategi yang lebih baik. Kemandirian pembelajar bukanlah konsep yang mudah. Untuk menjadi pembelajar yang memiliki tanggung jawab harus dilakukan secara bertahap. Pembelajar diarahkan secara bertahap untuk memiliki kepercayaan diri, keterlibatan, dan kemampuan berbahasa yang lebih besar.

c) Memperluas peran guru

Dengan menggunakan strategi belajar bahasa pengajar bukan dipandang secara tradisional sebagai figur otoritas dengan peran sebagai orang tua, instruktur, direktur, manajer, hakim, pemimpin, evaluator, pengawas, melainkan berperan sebagai fasilitator, pemandu, konsultan, penasihat, koordinator, narasumber, ahli diagnostik, dan komunikator. Pengajar mengidentifikasi strategi belajar dan melakukan pelatihan perihal penggunaan strategi belajar bahasa untuk membantu pembelajar menjadi lebih mandiri.

d) Berorientasi pada pemecahan masalah

Strategi belajar bahasa digunakan untuk memecahkan masalah sehingga pembelajar mencapai tujuan yang telah ditetapkan. Misalnya strategi afektif digunakan untuk membantu pembelajar yang memiliki tingkat kecemasan yang tinggi. Pembelajar tersebut dilatih agar bisa rileks ketika belajar bahasa sehingga dia memiliki kepercayaan diri yang lebih besar.

e) Merupakan tindakan spesifik yang diambil oleh pembelajar

Strategi pembelajaran bahasa adalah tindakan tertentu atau perilaku dilakukan oleh siswa untuk memecahkan masalah sehingga meningkatkan kemampuan mereka. Misalnya 
membuat catatan, merencanakan untuk tugas bahasa, mengevaluasi diri, dan menebak-nebak secara cerdas adalah tindakan yang dilakukan untuk mencapai tujuan.

f) Melibatkan banyak aspek belajar dari pembelajar, bukan hanya kognitif

Strategi pembelajaran bahasa tidak terbatas pada fungsi kognitif. Strategi juga mencakup fungsi metakognitif (seperti perencanaan, evaluasi, dan mengatur seseorang belajar sendiri), afektif, sosial, dan fungsi lainnya.

g) Mendukung pembelajaran baik secara langsung maupun tidak langsung

Beberapa strategi belajar melibatkan belajar secara langsung, yaitu langsung berkaitan dengan materi pembelajaran, yaitu berupa bahasa. Strategi yang demikian dikenal sebagai strategi langsung. Strategi lain, termasuk metakognitif, afektif, dan strategi sosial, berkontribusi tidak langsung namun memberi dukungan yang kuat untuk belajar. Strategi ini dikenal sebagai strategi tidak langsung. Strategi langsung dan tidak langsung sama-sama penting dan berfungsi untuk saling mendukung dalam banyak hal.

h) Tidak selalu bisa diamati

Strategi belajar bahasa tidak selalu mudah diamati. Bekerja sama dengan pembelajar lain untuk mencapai tujuan pembelajaran merupakan strategi yang dapat diamati, tetapi tindakan membuat asosiasi mental, strategi memori tidak bisa diamati.

i) Sering disadari

Penggunaan strategi belajar mencerminkan upaya sadar oleh pembelajar. Beberapa peneliti pun menyarankan agar strategi-strategi digunakan sebagai tindakan sadar. Dalam beberapa kasus, melalui sejumlah pelatihan, strategi belajar seperti keterampilan atau perilaku lainnya dapat menjadi otomatis.
Paradoks seperti tadi sering terjadi karena penggunaan strategi dilakukan oleh beberapa pembelajar secara naluriah, baik tepat ataupun tidak, tanpa dipikirkan dan tanpa dikritisi. Karena itu, penilaian penggunaan strategi dalam pelatihan diperlukan untuk membantu peserta didik menjadi lebih sadar akan strategi yang mereka gunakan dan untuk mengevaluasi kegunaan dari strategi tersebut.

j) Bisa diajarkan

Beberapa aspek dalam diri pembelajar seperti gaya belajar atau ciri kepribadian sangat sulit untuk berubah, sebaliknya strategi belajar lebih mudah diajarkan atau dimodifikasi. Hal ini dapat dilakukan melalui pelatihan strategi, yang merupakan bagian penting dari pendidikan bahasa. Bahkan pembelajar yang baik dapat meningkatkan penggunaan strategi mereka melalui pelatihan.

k) Fleksibel

Strategi belajar bahasa fleksibel, yaitu tidak selalu ditemukan dalam urutan atau dalam pola yang tepat. Terdapat banyak cara yang dilakukan pembelajar untuk memilih, menggabungkan, atau mengurutkan strategi. Misalnya, dalam membaca pembelajar menggunakan skimming atau scanning kemudian ketika mereka membaca lebih teliti mereka melakukan tindakan berupa mencatat atau meringkas.

1) Dipengaruhi oleh berbagai faktor Banyak faktor yang mempengaruhi pilihan strategi: tingkat kesadaran, tahap pembelajaran, jenis tugas, tujuan yang dirumuskan pengajar, usia, jenis kelamin, kebangsaan/etnis, gaya belajar umum, ciri-ciri kepribadian, tingkat motivasi, dan tujuan untuk belajar bahasa.

Lee (2010: 139) mengemukakan strategi belajar bahasa sejak tahun 1970 seperti yang dapat dilihat pada tabel berikut. 


\section{Tabel 1}

\section{Klasifikasi Strategi Belajar Bahasa sejak tahun 1970}

\begin{tabular}{|c|c|}
\hline Klasifikasi Strategi Belajar Bahasa & Peneliti dan Tahun \\
\hline $\begin{array}{l}\text { 1. Active task approach } \\
\text { 2. Realisation of language as a system } \\
\text { 3. Realisation of language as a means of } \\
\text { communication and interaction } \\
\text { 4. Management of affective demands } \\
\text { 5. Monitoring L2 performance }\end{array}$ & Naiman et.al (1970) \\
\hline $\begin{array}{l}\text { 1. Strategies that directly affect learning } \\
\text { - Clarification/verification } \\
\text { - Moritoring } \\
\text { - Memorisation } \\
\text { - Guessing/inductive inferencing } \\
\text { - Deductive reasoming } \\
\text { - Practice } \\
\text { 2. Processes that contribute indirectly to learring } \\
\text { - Creates cpportumities for practice } \\
\text { - Production tricks }\end{array}$ & Rubin (1981) \\
\hline $\begin{array}{l}\text { 1. Cognitive strategies } \\
\text { 2. Metacognitive strategies } \\
\text { 3. Social-affective strategies }\end{array}$ & Brown \& Palinscar (1982) \\
\hline $\begin{array}{l}\text { 1. Cognitive strategies } \\
\text { 2. Metacognitive strategies } \\
\text { 3. Social-affective strategies }\end{array}$ & O ‘Malley et.al. (1985) \\
\hline $\begin{array}{l}\text { Direct strategies: } \\
\text { 1. Memory strategies } \\
\text { 2. Cognitive strategies } \\
\text { 3. Compensation strategies } \\
\text { Indirect strategies: } \\
\text { 1. Metacognitive strategies } \\
\text { 2. Affective strategies } \\
\text { 3. Social strategies }\end{array}$ & Oxford (1990) \\
\hline
\end{tabular}

Menurut Lee (2010: 140) klasifikasi strategi belajar bahasa Oxford (1990) lebih komprehensif dan rinci. Untuk lebih jelasnya dapat dilihat pada tabel berikut.

\section{Tabel 2}

\section{Strategi Belajar Bahasa Oxford (1990)}

\begin{tabular}{|c|c|c|c|}
\hline \multirow{4}{*}{$\begin{array}{c}\text { Strategi } \\
\text { Langsung }\end{array}$} & \multirow{4}{*}{$\begin{array}{l}\text { Strategi } \\
\text { Memori }\end{array}$} & $\begin{array}{l}\text { A. Menciptakan } \\
\text { hubungan mental }\end{array}$ & $\begin{array}{l}\text { 1. Mengelompokkan } \\
\text { 2. Mengasosikan/elaborasi } \\
\text { 3. Menggunakan kata-kata baru } \\
\text { dalam konteks }\end{array}$ \\
\hline & & $\begin{array}{l}\text { B. Menggunakan imaji } \\
\text { dan bunyi-bunyi }\end{array}$ & $\begin{array}{l}\text { 1. Menggunakan imajeri } \\
\text { 2. Memetakan semantik } \\
\text { 3. Menggunakan kata kunci } \\
\text { 4. Merepresentasikan suara dalam } \\
\text { memori }\end{array}$ \\
\hline & & $\begin{array}{l}\text { C. Mengulang dengan } \\
\text { tuntas }\end{array}$ & 1. Meninjau kembali struktur \\
\hline & & D. Menggunakan tindakan & 1. Menggunakan respon fisik atau \\
\hline
\end{tabular}




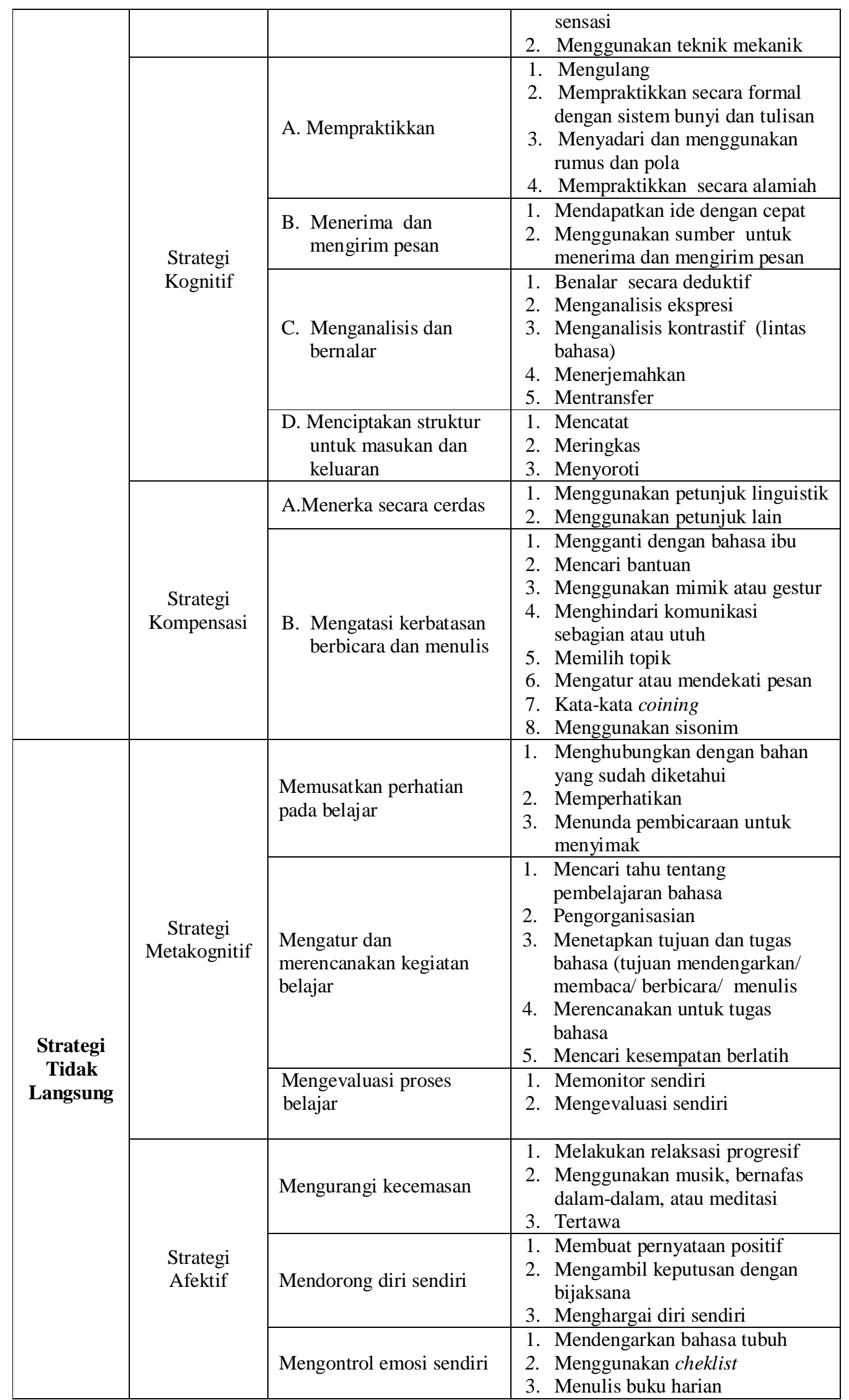




\begin{tabular}{|c|c|c|}
\hline & & $\begin{array}{l}\text { pembelajaran bahasa } \\
\text { 4. } \text { Membahas perasaan orang lain }\end{array}$ \\
\hline \multirow{3}{*}{$\begin{array}{l}\text { Strategi } \\
\text { Sosial }\end{array}$} & Bertanya & $\begin{array}{l}\text { 1. Bertanya untuk mengklarifikasi } \\
\text { atau verifikasi } \\
\text { 2. Bertanya untuk mengoreksi }\end{array}$ \\
\hline & Bekerja sama & $\begin{array}{l}\text { 1. Bekerja sama dengan teman } \\
\text { 2. Bekerja sama dengan pemakai } \\
\text { bahasa baru yang mahir }\end{array}$ \\
\hline & $\begin{array}{l}\text { Berempati kepada } \\
\text { yang lain }\end{array}$ & $\begin{array}{l}\text { 1. Mengembangkan pemahaman } \\
\text { budaya } \\
\text { 2. Menyadari pikiran dan perasaan } \\
\text { orang lain }\end{array}$ \\
\hline
\end{tabular}

Menurut Oxford (1990: 24) langkah-langkah penggunaan strategi belajar bahasa adalah (1) menentukan kebutuhan pembelajar dan waktu yang tersedia, (2) memilih strategi dengan baik, (3) mengkaji integrasi dari pelatihan strategi, (4) mengkaji cara memotivasi, (5) menyusun materi dan kegiatan, (6) melakukan pelatihan dengan informasi yang lengkap, (7) mengevaluasi pelatihan strategi meninjau kembali pelatihan strategi.

O'Malley dan Chamot (1990) mengemukakan 3 model langkahlangkah penggunaan strategi belajar bahasa, yaitu model SBBI yang yang dikembangkan oleh Cohen (1998), model CALLA yang dikembangkan oleh O'Malley dan Chamot (1990: 34) dapat dilihat pada tabel berikut.

Tabel 3

Model-Model Instruksi pada Strategi Belajar Bahasa

\begin{tabular}{|c|c|c|}
\hline $\begin{array}{l}\text { SSBI* Model } \\
\text { (Cohen, 1998) }\end{array}$ & $\begin{array}{l}\text { CALLA** Model (C hamot, } \\
\text { 2005; Chamot et al., 1999) }\end{array}$ & Grenfell \& Harris (1999) \\
\hline $\begin{array}{l}\text { Guru sebagai ahli diagnostik: } \\
\text { Membantu pembelajar } \\
\text { engidentifikasi } \\
\text { strategi dan gaya belajar. }\end{array}$ & $\begin{array}{l}\text { Persiapan: } \\
\text { Guru mengidentifikasi strategi } \\
\text { belajar pembelajar untuk tugas- } \\
\text { tugas akrab. }\end{array}$ & $\begin{array}{l}\text { Peningkatan kesadaran: } \\
\text { Pembelajar melengkapi tugas, dan } \\
\text { kemudian mengidentifikasi } \\
\text { strategi yang mereka gunakan. }\end{array}$ \\
\hline $\begin{array}{l}\text { Guru sebagai pembelajar } \\
\text { bahasa } \\
\text { pembelajar: memiliki } \\
\text { pengalaman belajar dan pemikiran } \\
\text { proses }\end{array}$ & $\begin{array}{l}\text { Presentasi: } \\
\text { Model Guru, nama, menjelaskan } \\
\text { strategi baru; meminta pembelajar } \\
\text { apakah dan bagaimana mereka telah } \\
\text { menggunakannya. }\end{array}$ & $\begin{array}{l}\text { Modeling: } \\
\text { Guru sebagai model membahas } \\
\text { nilai strategi baru, membuat } \\
\text { checklist strategi untuk digunakan } \\
\text { nanti. }\end{array}$ \\
\hline $\begin{array}{l}\text { Guru sebagai pelatih } \\
\text { pembelajar: } \\
\text { Melatih pembelajar bagaimana } \\
\text { menggunakan strategi } \\
\text { pembelajaran. }\end{array}$ & $\begin{array}{l}\text { Praktik: } \\
\text { Pembelajar mempraktikkan strategi } \\
\text { baru dalam praktik berikutnya, guru } \\
\text { menjadi pengingat untuk } \\
\text { mendorong penggunaan strategi } \\
\text { independen }\end{array}$ & $\begin{array}{l}\text { Praktik umum: } \\
\text { Pembelajar mempraktikkan } \\
\text { strategi-strategi baru dengan } \\
\text { tugas yang berbeda. }\end{array}$ \\
\hline $\begin{array}{l}\text { Guru sebagai koordinator: } \\
\text { Mengawasi rencana belajar dan } \\
\text { memonitor kesulitan pembelajar }\end{array}$ & $\begin{array}{l}\text { Evaluasi Diri: } \\
\text { Pembelajar mengevaluasi } \\
\text { penggunaan strategi mereka sendiri } \\
\text { segera setelah latihan. }\end{array}$ & $\begin{array}{l}\text { Perencanaan tindakan: } \\
\text { Pembelajar menetapkan tujuan } \\
\text { dan memilih strategi untuk } \\
\text { mencapai tujuan. }\end{array}$ \\
\hline $\begin{array}{l}\text { Gurusebagai pelatih: } \\
\text { Membimbing keberlangsungan } \\
\text { kemajuan pembelajar' }\end{array}$ & $\begin{array}{l}\text { Ekspansi: } \\
\text { Pembelajar mentransfer strategi } \\
\text { untuk tugas-tugas baru, } \\
\text { menggabungkan strategi ke dalam } \\
\text { kelompok, mengembangkan } \\
\text { repertoar disukai strategi. }\end{array}$ & $\begin{array}{l}\text { Latihan terfokus: } \\
\text { Pembelajar menggunakan } \\
\text { strategi yang dipilih; guru } \\
\text { meminta agar pembelajar } \\
\text { menggunakan strategi otomatis. }\end{array}$ \\
\hline
\end{tabular}




\begin{tabular}{|l|l|l|}
\hline & & \\
\hline & $\begin{array}{l}\text { Penilaian: } \\
\text { Guru menilai penggunaan strategi oleh } \\
\text { pembelajar dan dampaknya pada } \\
\text { kinerja pembelajar. }\end{array}$ & $\begin{array}{l}\text { Evaluasi: } \\
\text { Guru dan pembelajar mengevaluasi } \\
\text { keberhasilan dari rencana tindakan; } \\
\text { mengatur tujuan baru, siklus dimulai } \\
\text { lagi. }\end{array}$ \\
\hline
\end{tabular}

* Styles and Strategies-Based Instruction

** Cognitive Academic Language Learning Approach

Berdasarkan pendapat tadi dapat dinyatakan bahwa strategi belajar bahasa digunakan sesuai dengan kebutuhan. Huda (1999: 27-28) mengemukakan bahwa bentuk penggunaan strategi belajar bahasa bisa dilakukan melalui pelatihan dalam bentuk kuliah umum atau lokakarya umum untuk menggugah kesadaran peserta, kerja bersama saling memberi bantuan (tutor) tentang kesulitan belajar, menyisipkan materi strategi belajar bahasa dalam buku teks pelajaran bahasa, rekaman video berisi kuliah pendek tentang strategi belajar, dan pengajaran berbasis strategi belajar bahasa.

Huda (1999: 27) menjelaskan lebih lanjut bahwa dalam bentuk pengajaran berbasis strategi belajar bahasa, strategi belajar bahasa dimasukkan dalam materi atau tugas pelajaran bahasa yang diberikan oleh pengajar secara reguler, pengintegrasian materi tersebut beserta penjelasannya dilakukan dan diberikan baik secara eksplisit maupun implisit dengan maksud memberikan konteks yang bermakna bagi peserta untuk berlatih menggunakannya.

Salah satu contoh pembelajaran bahasa berbasis strategi belajar bahasa adalah pembelajaran yang dilakukan oleh Cohen, dkk. (1996). Cohen dkk. melakukan penelitian penggunaan strategi belajar bahasa dalam pembelajaran berbicara. Sebelum pelatihan dimulai, strategi belajar bahasa yang akan dilatihkan, ditawarkan kepada pembelajar dan pembelajar memilih dan menggunakannya dalam pelatihan berbicara. Berbicara yang dilatihkan adalah mendeskripsikan diri, menceritakan kembali, dan menjelaskan kota.

Strategi belajar bahasa yang ditawarkan kepada pembelajar adalah sebagai berikut.

\section{STRATEGI BERBICARA}

(Dirancang oleh C. Alcaya, K. Lybeck, \& P. Mougel, guru dalam eksperimen strategi berbicara, NLRC/CARLA, Universitas Minnesota, November 1994) (Cohen, 1996: 48-51)

1) Sebelum Anda Berbicara Menurunkan Kecemasan Anda

- menarik nafas

- berbicara positif tentang diri sendiri

- membayangkan diri Anda berhasil

- teknik relaksasi

- merasa siap

- teknik menurunkan kecemasan lainnya?

Mempersiapkan dan Merencanakan

- Mengidentifikasi tujuan dan tujuan dari tugas: Apa yang harus Anda pelajari atau harus tunjukkan dalam latihan ini?

- Mintalah penjelasan tentang tugas jika Anda tidak yakin akan tujuannya atau tujuan, atau bagaimana Anda melakukannya.

- Aktifkan latar belakang pengetahuan yang Anda ketahui yang berkaitan dengan situasi/tugas - Menghubungkan tugas untuk situasi yang sama, membuat asosiasi. - Memprediksi apa yang akan terjadi: memprediksi kosakata yang Anda perlukan; membuat peta kata; mengelompokkan; memikirkan tentang bagaimana Anda mengganti kosa kata yang tidak Anda ketahui; memikirkan sinonim, antonim, penjelasan, atau 
komunikasi nonverbal yang dapat menggantikan; memprediksi struktur (grammar) yang Anda butuhkan; meninjau tugas sejenis dalam buku Anda; mentransfer kosa kata dan struktur yang telah dipelajari sebelumnya dalam situasi baru. Memprediksi kesulitan yang mungkin Anda alami.

\section{Rencanakan tanggapan dan kontribusi Anda}

- Organisasikan pikiran Anda.

- Siapkan outline umum (gunakan catatan, kata kunci, gambar menarik)

- Memprediksi apa yang akan dikatakan pihak lain .

- Berlatih (berlatih diam-diam, beraksi di depan cermin)

- Bekerja sama dalam semua bidang jika ada tugas kelompok.

- Mendorong diri Anda untuk berbicara, meskipun Anda mungkin membuat beberapa beberapa kesalahan.

\section{2) Saat Anda Berbicara} Mengendalikan Perasaan

- Atur suhu emosional Anda. Jika Anda merasa, cobalah untuk bersantai, menyalurkan energi Anda ke pikiran Anda (tertawa, bernapas dalam-dalam).

- Berkonsentrasi pada tugas, jangan membiarkan yang terjadi di sekitar Anda mengalihkan perhatian Anda.

- Gunakan bahan yang telah Anda persiapkan (bila memungkinkan).

- Mintalah klarifikasi, bantuan, atau verifikasi sebagai bahan masukan bagi peningkatan kemampuan Anda

- Keterlambatan berbicara, tidak apa-apa untuk mengambil waktu untuk berpikir sampai muncul respon Anda.

- Jangan menyerah. Jangan membiarkan kesalahan-kesalahan Anda menghentikan Anda. Jika Anda merasa terpojok atau merasa frustrasi, Anda meminta waktu, dan mulai beralih ke arah lain.

- Pikirkan dalam bahasa target.

- Mendorong diri Anda (menggunakan positif self-talk).

\section{Terlibat dalam Percakapan}

- Arahkanlah pikiran Anda jauh dari situasi yang menegangkan (misalnya, tes!)

Berkonsentrasilah pada percakapan. - Dengarkan lawan bicara Anda. Sering kali Anda akan dapat menggunakan struktur atau kosa kata yang mereka gunakan dalam respons Anda sendiri. - Bekerja sama untuk menegosiasikan makna dan untuk menyelesaikan tugas. - Mengantisipasi apa yang dikatakan orang lain berdasarkan apa yang telah dikatakan sejauh ini.

- Berempati dengan pasangan Anda. Cobalah untuk mendukung dan membantu.

- Gunakan pertimbangan yang rasional. Jangan asal mengira-ngira, tetapi menggunakan pertimbangan yang baik untuk tampil pergi dan berbicara pada waktu yang tepat, bukan diam karena takut membuat kesalahan.

\section{Memantau Kinerja Anda}

- Memantau pembicaraan Anda dengan memperhatikan kosakata Anda, tata bahasa, dan pengucapan saat berbicara.

- Perbaiki sendiri jika Anda mengetahui sendiri kesalahan Anda.

- Aktifkan kosakata baru Anda. Cobalah untuk tidak hanya mengandalkan pada kata-kata yang akrab

- Meniru cara penutur asli berbicara.

- Mengganti kata dengan menggunakan strategi seperti sinonim, menebak kata yang digunakan, mendapatkan bantuan, dengan menggunakan rumpun, membuat kata-kata, menggunakan gerakan

- Sesuaikan atau perkirakan pesan Anda. Jika Anda tidak dapat mengomunikasikan kompleksitas ide Anda, berkomunikasilah melalui pertanyaan dan jawaban. Anda akan dapat menutupi ketidakmampuan dalam mengomunikasikan ide.

- Beralih (bila mungkin) pada topik yang Anda ketahui kata-katanya. 
(Jangan lakukan ini untuk berlatih materi baru, bagaimanapun!)

\section{3) Setelah Anda Berbicara}

Mengevaluasi Kinerja Anda

- Hadiahi diri Anda dengan positif selftalk untuk menyelesaikan tugas. Beri diri Anda hadiah secara pribadi bermakna untuk terutama untuk kinerja yang baik. - Mengevaluasi seberapa baik kegiatan itu dicapai (Apakah Anda menyelesaika tugas,

mencapai tujuan? Jika tidak, apa yang akan Anda lakukan secara berbeda pada kesempatan lain?)

- Mengidentifikasi area masalah.

- Berbagi dengan teman sebaya dan instruktur (meminta dan memberikan umpan balik, berbagi strategi belajar).

- Sadarilah pikiran dan perasaan orang lain.

\section{Rencana untuk Tugas-tugas yang} Akan Datang

- Rencanakan bagaimana Anda akan meningkatkan kemampuan untuk waktu berikutnya.

- Pelajarilah bentuk kosakata dan tata bahasa yang sulit Anda ingat

- Gunakan strategi checklist untuk melihat apa yang mungkin Anda miliki terlupakan.

- Meminta bantuan untuk mengoreksi.

- Bekerja dengan pemakai bahasa target yang mahir.

- Gunakan strategi dokumen yang digunakan dan hasil tugas, untuk mengetahui apa saja yang telah Anda kerjakan

Dalam pelatihan berbicara mendeskripsikan diri, para pembelajar diminta untuk menjemput seseorang di bandara (pembicara asli Perancis/Norwegia yang tidak berbicara bahasa Inggris). Berdasarkan strategi belajar bahasa yang ditawarkan, pembelajar memilih strategi belajar bahasa dalam pelatihan berbicara mendeskripsikan diri sebagai berikut.

\section{Sebelum Berbicara}

1) menerjemahkan kata-kata khusus dari bahasa Inggris (strategi kognitif)

2) mencoba untuk memvisualisasikan bandara (strategi kompensasi)

3) memikirkan tugas-tugas serupa yang telah dilakukan (strategi metakognitif)

\section{Selama Berbicara}

1) memperhatikan pengucapan (strategi metakognitif)

2) bila tidak bisa mengingat kata, diganti dengan kata/frase lain (strategi kompensasi)

3) bila tidak bisa mengingat kata dan melewatkan bagian dalam deskripsi (strategi

kompensasi)

4) menggunakan catatan yang ditulis sebelum tugas (strategi kognitif)

5) bekerja dengan cepat dan tidak banyak perhatian terhadap apa yang dikatakan (strategi kognitif)

\section{Setelah Berbicara}

1) belajar sesuatu yang baru/berguna tentang bahasa target selama tugas. (strategi memori)

2) segera mulai mengisi checklist tentang kinerja sendiri tanpa banyak berpikir (Strategi Metakognitif)

Kriteria penilaian yang digunakan untuk kemampuan berbicara mendeskripsikan diri adalah sebagai berikut

1) menunjukkan kepercayaan diri dalam pengiriman - kelancaran dalam berbicara, jeda yang jelas, menemukan materi yang sesuai tidak kehilangan kata-kata

2) keberterimaan tata bahasa - yaitu, subjek-verba, orang, nomor, dan tenses, penggunaan negasi dan artikel yang bena 
3) ketepatan kosakata - yaitu, variasi dalam pilihan kata, kesesuaian dengan konteks.

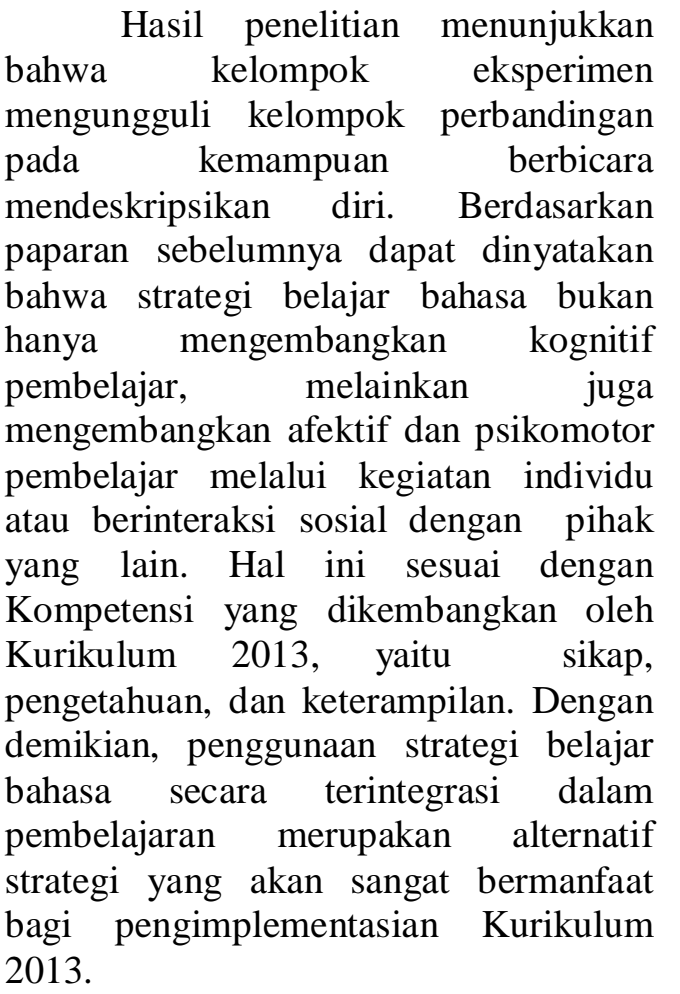

\section{SIMPULAN}

$\begin{array}{ccr}\text { Pembelajaran } & \text { bahasa berbasis } \\ \text { strategi belajar bahasa adalah }\end{array}$ pembelajaran yang didasarkan pada caracara yang dilakukan oleh pembelajar untuk meningkatkan kemampuan berbahasanya, baik reseptif maupun produktif, baik lisan maupun tulisan. Strategi belajar bahasa merupakan strategi yang memberi peluang kepada pembelajar untuk membangun kognitif, afektif, dan psikomotor, baik melalui kegiatan individu atau berinteraksi sosial dengan pembelajar yang lain, guru, intruktur, atau yang lainnya. Hal ini sesuai dengan tutntutan Kurikulum 2013 yang membangun kepribadian pembelajar secara utuh yang meliputi sikap, pengetahuan, dan keterampilan.

Dalam pelaksanaan Kurikulum 2013 penggunaan strategi belajar digunakan sesuai dengan kebutuhan. Bentuk-bentuk penggunaannya bisa dilakukan melalui pelatihan dalam bentuk kuliah umum atau lokakarya umum untuk menggugah kesadaran peserta, kerja bersama saling memberi bantuan (tutor) tentang kesulitan belajar, menyisipkan materi strategi belajar bahasa dalam buku teks pelajaran bahasa, rekaman video berisi kuliah pendek tentang strategi belajar, atau pembelajaran berbasis strategi belajar bahasa.

\section{UCAPAN TERIMA KASIH}

Artikel ini terwujud atas bantuan dari berbagai pihak. Karena itu, pada kesempatan ini penulis mengucapkan terima kasih kepada (1) Rektor Universitas Siliwangi Tasikmalaya, Prof. Dr. H. Kartawan, M.P. yang telah memfasilitasi penyelesaian artikel ini; (2) Dekan FKIP Universitas Siliwangi Tasikmalaya, Prof. Dr. H. Yus Darusman, M.Pd. yang selalu mendorong penulis untuk selalu berkarya secara ilmiah; (3) Rekan-rekan di Program Studi Pendidikan Bahasa dan Sastra Indonesia, FKIP Universitas Siliwangi Tasikmalaya yang telah memberikan saran untuk penyempurnaan artikel ini; (4) Panitia Forum Ilmiah FPBS Universitas Pendidikan Indonesia Bandung 2013 yang telah memberikan kesempatan untuk penulisan artikel ini, dan (4) Redaktur Jurnal Bahasa \& Sastra, FPBS Universitas Pendidikan Indonesia Bandung atas dimuatnya artikel ini

\section{PUSTAKA RUJUKAN}

Azrien, dkk. 2011. "Language Learning Strategies and Self-Efficacy Belief in Arabic Language Learning: A Malaysian Context". AJTLHE Vol. 3, No.2, July 2011, 48-59. ISSN: 1985-5826. [Online]. Tersedia di: http://www.ukm.my/jtlhe/pdf/AJ TLHE 78-En Mohahamad Azrien 
UM KB.pdf. [Diakses 22 Februari 2o14]'

Cohen, Andrew D., dkk. 1996. "The Impact of Strategies-Based Instruction on Speaking a Foreign Language". Research Report Center for Advanced Research on Language Acquisition. [Online].Tersedia di :http://www.carla.umn,edu/about/ profiles/ CohenPapers/ SBImpact.pdf. [Diunduh pada tanggal 19 Februari 2013].

Cohen, Andrew D. 1998. Strategies in Learning and Using A Second Language. New York: Longman.

Ehrman, Madeline dan Rebecca Oxford. 2008. "Adult Language Learning Styles and Strategies in an Intensive Training Setting". Foreign Service Institute College of Education1501 S. Randolph Street University of AlabamaArlington, VA 22204 Tuscaloosa,AL. [Online]. Tersedia di: http://www.academia.edu/234409 5/ adult language learning styles a $\underline{\text { nd }}$

strategies in an intensive traini ng _setting. [Diakses 18 Maret 2013].

Huda, Nuril. 1999. "Menuju Pengajaran Bahasa Berbasis Strategi Belajar: Implikasi Kajian Strategi Belajar Bahasa Kedua”. Pidato Pengukuhan Guru Besar dalam Bidang Ilmu Pemerolehan Bahasa Kedua pada Fakultas Pendidikan Bahasa dan Seni IKIP Malang. [Online]. Tersedia di:

http://library.um.ac.id/images/sto ries/pidatogurubesar/ gurubesar/ MenujuPengajaranBahasa

Berbasis Strategi Belajar Implikasi Kajian Strategi Belajar Bahasa Kedua-Prof. H.Nuril
Huda, M.A. Ph.D.pdf. [Diakses 8 Oktober 2013]

Iskandarwassid dan Dadang Sunendar. 2008. Strategi Pembelajaran Bahasa. Bandung: Program Pascasarjana UPI dan PT Remaja Rosdakarya.

Lee, Chien Kuo. 2010. “An Overview of Language Learning Strategies". ARECLS, 2010, Vol.7,132- 152. [Online]. Tersedia di :http://research.ncl.ac.uk/ARECL S/volume7/lee vol7.pdf. [Diakses 18 Maret 2013].

Muho, Anita dan Aida Kurani. 2011. "Learning Strategies in Second Language Learning and Teaching". Mediterranean Journal of Social Sciences Vol. 2, No. 3, September 2011; ISSN 2039-2117. Halaman 174-178. [Online]. Tersedia di http://www.mcser.org/images/sto ries/2_journal/mjssso203septemb er2011/17. anitamuho.pdf. [Diakses 19 Februari 2014\}.

O’Malley, I. Michael. and Anna Uhl Chamot, 1990. Learning Strategies in Second Language Axquisition, New Yoek: Cambridge University Press.

Oxford, Rebecca L. 1990. Language Learning Strategies: What Every Teacher Should Know. New York: Newbury House Publishers.

Learning Styles and Strategies: an Overview". Gala. [Online]. Tersedia di:http://hyxy.nankai.edu.cn/. jingpinke/buchongyuedu/learning strategiesOxford.pdf. [Diakses 20 Agustus 2013].

Peraturan Menteri Pendidikan dan Kebudayaan Republik Indonesia Nomor 54 Tahun 2013 tentang Standar Kompetensi Lulusan Pendidikan Dasar dan Menengah.

Peraturan Menteri Pendidikan dan Kebudayaan Republik Indonesia 
Nomor 65 Tahun 2013 tentang Standar Proses Pendidikan Dasar dan Menengah.

Querol, Marites B. 2010. College Students' Use of Affective and Social Language Learning Strategies: A Classroom-Based Research. Philippine ESL Journal, Vol. 5, July 2010 (C) 2010 Time Taylor International ISSN 1718-2298. [Online]. Tersedia di: Tersedia: http://www.philippine-esljournal.com/V5 A8.pdf. [Diakses 8 Maret 2013].

Su, Min-Hsun Maggie. 2005. "A Study of EFL Technological and Vocational College Students' Language Learning Strategies and Their Self-Perceived English Proficiency". Electronic Journal of Foreign Language Teaching. Vol. 2, No. 1, Pp. 44-56. [Online]. Tersedia di: http://eflt.nus.edu.sg. [18 Maret 2013].

Wenden, Anita dan Joan Rubin. 1987. Learner strategies in Language Learning. New York: Prentice Hall. 